\title{
INTERNALISASI NILAI-NILAI MULTIKULTURAL DALAM PEMBELAJARAN PENDIDIKAN AGAMA ISLAM DI SEKOLAH (Pendidikan Tanpa Kekerasan)
}

\author{
$\underline{\text { Sapendi }}$ \\ Dosen PGRA IAIN Pontianak \\ Email: pendy_unj@yahoo.co.id
}

\begin{abstract}
Multicultural education is a false sosial device to boost the schools' participation in order to build the awareness of multicultural society. It will be useful to strengthen the tolerance to realize the ability of working together above the differences. Teachers are the important roles on spreading the multicultural values to create the harmonious community. Furthermore, teachers are expected to introduce the symbols of nationality insight through the education process in the class or in the vast society. Besides, teachers are supposed to actively participate on the development of multiculturalism in Indonesia. So that, the exclusivity which triggers the interpersona or group conflict could be decreased. Teachers, particularly the religion teacher should teach not only the values in the religion's rituals, but also the universal values, such as justice, equality, bumanity, kindness, honesty, and so on. Therefore, the religion teacher should thoughtfully profound the universal concepts believed by their own religion.
\end{abstract}

Keywords: Multicultural Education, Teachers

\section{PENDAHULUAN}

Indonesia adalah negara yang paling majemuk baik dari segi sosio-kultural maupun geografis. Dengankata lain, Indonesia merupakan salah satu negara multikultural terbesar di dunia. Sekarang ini, jumlah pulau di Negara Kesatuan Republik Indonesia (NKRI) sekitar 13.000 pulau besar dan kecil, lebih dari 200 juta jiwa penduduk dengan 300 suku dan menggunakan hampir 200 bahasa yang berbeda. Selain itu, mereka juga menganut agama dan kepercayaan yang beragam.Lebih khusus lagi, apabila dilihat dari cara pandang, tindakan dan wawasan setiap individu yang berbeda terhadap berbagai macam fenomena sosial, budaya, ekonomi, politik dan terhadap hal-hal lainny.Maka tak dapat dipungkiri mereka memiliki pandangan yang beragam (M. Ainul Yaqin, 2007).

Negara bangsa Indonesia terdiri atas sejumlah besar kelompok-kelompok etnis, budaya, agama dan lain-lain.Hefner (2007:16) mengilustrasikan Indonesia sebagaimana juga Malaysia dan Singapura memiliki warisan dan tantangan pluralisme budaya (cultural pluralism) secara lebih mencolok, sehingga dipandang sebagai lokus klasik bagi bentukan baru masyarakat majemuk (plural society). Kemajemukan masyarakat Indonesia paling tidak dapat dilihat dari dua cirinya yang unik, pertama secara horizontal, ia ditandai oleh kenyataan adanya kesatuan-kesatuan sosial berdasarkan perbedaan suku bangsa, agama, adat, serta perbedaan kedaerahan, dan kedua secara vertikal ditandai oleh adanya perbedaan-perbedaan vertikal antara lapisan atas dan lapisan bawah yang cukup tajam (Nasikun, 2007:33). Kondisi di atas tergambar dalam prinsip bhinneka tunggal ika, yang berarti meskipun Indonesia adalah berbbinneka, tetapi terintegrasi dalam kesatuan

Namun demikian, pengalaman Indonesia sejak masa awal kemerdekaan, khususnya pada masa demokrasi terpimpin Presiden Soekarno dan masa Orde Baru Presiden Soeharto memperlihatkan kecenderungan kuat pada politik monokulturalisme (Azra, 2006:152). Lebih lanjut Azra (2006:152) mengemukakan bahwa dalam politik ini, yang diberlakukan bukannya 
penghormatan terhadap keragaman (kebhinnekaan, atau multikulturalisme), tetapi sebaliknya adalah keseragaman (monokulturalisme) atas nama stabilitas untuk pembangunan.

Multikultural adalah kenyataan yang harus diterima oleh umat manusia, karena itu, kenyataan tersebut tidak harus membuat umat manusia yang berasal dari kultur yang berbeda menjadi terpecahbelah dan saling memusuhi satu sama lain. Sekalipun demikian, sejarah umat manusia telah membuktikan, banyak kisah sedih yang memilukan yang diakibatkan oleh adanya pertentangan antar kelompok kultur yang berbeda (agama, etnis, ras, dll)

Keanekaragaman kultur, khususnya keragaman agama, suku, dan ras secara langsung ataupun tidak telah memberikan banyak tantangan bagi umat manusia. Konsekwensi tersebut salah satunya, adalah timbulnya potensi konflik untuk saling bertentangan. Hampir di semua negara terjadi konflik kekerasan antar warga yang memiliki latar belakang yang berbeda, baik dikarenakan oleh perbedaan agama, suku, ras, warna kulit, maupun perbedaan-perbedaa lainnya.

Kekerasan-kerasan yang dilatarbelakangi oleh perbedaan-perbedaan di atas juga terjadi di Indonesia, bahkan cenderung menguat dalam beberapa tahun terakhir ini. Konflik yang berlatarbelakang agama seperti yang terjadi di Ambon dan Poso adalah contoh konflik yang dilatarbelakangi oleh perbedaan agama. Konflik kekerasan yang dilatarbelakangi oleh perbedaan etnik tertentu juga terjadi di Kalimantan Barat, yang mulai meletus sejak tahun 1933, 1967, 1968, 1976, 1977, 1979, 1983, 1993, 1996, 1997. Selain konflik-konflik ini masih terdapat konflikkonflik lainnya, yang meskipun dalam skala yang relatif kecil (M. Ainul Yaqin, 2005).

Berangkat dari keprihatinan di atas, perlu kiranya dicarikan strategi khusus sebagi solusi dalam memecahkan persoalan tersebut melalui berbagai bidang; sosial, politik, budaya, ekonomi dan pendidikan. Bidang pendidikan merupakan bidang yang dipandang paling potensial untuk menanamkan nilai-nilai kebersamaan, pesatuan, dan kedekatandi antara keragaman etnik, ras, agama, dan budaya. Karena lembaga pendidikan berfungsi untuk melakukan integrasi sosial, yakni menyatukan anak-anak dari berbagai sub budaya yang beragam dan mengembangkan masyarakat yang memiliki nilai-bersama yang relatif hetrogen.

Lembaga pendidikan diharapkan dapat menanamkan sikap kepada peserta didik untuk menghargai orang, budaya, agama, dan keyakinan lain. Harapannya, dengan implementasi pendidikan yang berwawasan multikultural, akan membantu siswa mengerti, menerima dan menghargai orang lain yang berbeda suku, budaya dan nilai kepribadian. Lewat penanaman semangat multikulturalisme di sekolah-sekolah, akan menjadi medium pelatihan dan penyadaran bagi generasi muda untuk menerima perbedaan budaya, agama, ras, etnis dan kebutuhan di antara sesama dan mau hidup bersama secara damai.

Agar proses ini berjalan sesuai harapan, maka seyogyanya kita mau menerima jika pendidikan multikultural disosialisasikan dan didiseminasikan melalui lembaga pendidikan, serta, jika mungkin, ditetapkan sebagai bagian dari kurikulum pendidikan di berbagai jenjang baik di lembaga pendidikan pemerintah maupun swasta. Apalagi, paradigma multikultural secara implisit juga menjadi salah satu concern dari Pasal 4 UU N0. 20 Tahun 2003 Sistem Pendidikan Nasional. Dalam pasal itu dijelaskan, bahwa pendidikan diselenggarakan secara demokratis, tidak diskriminatif dengan menjunjung tinggi HAM, nilai keagamaan, nilai kultural dan kemajemukan bangsa

Penanaman nilai-nilai multikultural tidak harus menjadi mata pelajaran tersendiri. Tetapi, dapat diintegrasikan dalam mata pelajaran yang sudah ada, seperti pelajaran agama dan pendidikan kewarganegaran. Khusus dalam pelajaran agama, mengingat agama merupakan aspek 
kehidupan yang sangat penting dalam masyarakat, khsusnya masyarakat Indonesia. Pendidikan agama, selain bertujuan menamkan nilai-nilai keimanan dan ketaqwaan kepada peserta didik, juga bertujuan untuk mengembangakan sikap toleransi dan sikap saling menghormati terhadap setiap perbedaan masing-masing peserta didik (agama, suku, ras, dll). Karena perbedaan merupakan taqdir yang sudah ada sejak manusia ada di muka bumi ini. Maka sudah sewajarnya kalau perbedaan itu diterima dan disikapi dengan arif oleh stiap individu.

Dalam kaitannya dengan hal tersebut, tentunya pendidikan agama sebagai media penyadaran umat dihadapkan pada problem bagaimana mengembangkan pola keberagamaan berbasis inklusivisme, pluralis dan multikultural, sehingga pada akhirnya dalam kehidupan masyarakat tumbuh pemahaman keagamaan yang toleran, inklusif dan berwawasan multikultural. Sebab dengan tertanamnya kesadaran demikian, sampai batas tertentu akan menghasilkan corak paradigma beragama yang hanief (lurus). Ini semua mesti dikerjakan pada level bagaimana membawa pola pembelajaran pendidikan agama disekolah dalam paradigma yang toleran dan inklusif. (Abd.Bakar, 2006; 36).

Seiring berkembangnya pola kehidupan yang majemuk / heterogen, maka tak berlebihan jika paradigma pembelajaran pendidikan agama Islam perlu dikaji ulang dengan pengenalan pendidikan multicultural kepada peserta didik. Lantas bagaimana pola pembelajaran pendidikan Agama Islam berbasis multikultural dapat diterapkan? Menurut Muhaimin (2007;40), ada tiga kunci pokok yang dapat dipakai untukmengembangkan pendidikan multikultural. Pertama, diintegrasikan melalui pembelajaran dengan metode diskusi pada kelompok-kelompok kecil. Kedua, berupa kepekaan terhadap informasi terutama berkaitan isu-isu masyarakat multikultural, sebab didalamnya terdapat ethno-kultural dan agama, demokrasi dan pluralitas, kemanusiaan universal dan subyek lain yang relevan. Ketiga, mengubah paradigma dengan menanamkan sikap saling menghormati, tulus dan toleran terhadap keanekaragaman budaya ditengah masyarakat, dengan memperkuat basik spiritual yang peka terhadap masalah sosial-keagamaan.

Dengan pendekatan pembelajaran pendidikan agama berbasis multikultural sebagaimana uraian di atas, kita berharap tercipta tata kehidupan yang menghargai pluralitas, toleran dan mengupayakan kehidupan damai. Disamping itu, juga diharapkan mampu membentuk kesalehan pribadi dan kesalehan sosial pada diri pelajar, sehingga pendidikan agama diharapkan jangan sampai menumbuhkan semangat kefanatikan berlebihan sehinga bersikap intoleran, yang tentunya, akan memperlemah kerukunan hidup beragama dan persatuan nasional.

Guru merupakan pelaku penting dalam penebaran nilai-nilai multikultural untuk membangun suatu komunitas yang harmonis bangsa ini. Guru diharapkan bisa menebarkan simbol-simbol wawasan kebangsaan melalui proses pembelajaran di dalam kelas maupun dalam masyarakat yang lebih luas. Para guru, diharapkan dapat berperan aktif terhadap pengembangan multikulturalisme di Indonesia, sehingga pertumbuhan eksklusifisme, yang dapat mengundang konflik intra dan antar kelompok, dapat berkurang.

Guru, khususnya guru agama dalam mengajarkan pelajaran agama, hendaknya tidak hanya mengajarkan nilai-nilai partikular ritual-ritual agama, tetapi juga diharapkan dapat mengajarkan nilai-nilai universal, seperti keadilan, kesetaraan, kemanusiaan, berbuat baik terhadap sesama, kejujuran dan lain sebagainya. Karena itu, guru agama (semua agama) hendaknya benarbenar memahami konsep-konsep universal yang dianut oleh agamanya masing-masing. 


\section{SEJARAH MULTIKULTURALISME}

Dalam sejarahnya menurut Melani Budinata, multikulturalisme diawali dengan teori melting pot yang sering diwawancarakan oleh J.Hector seorang imigran asal Normandia. Dalam teorinya Hector menekankan penyatuan budaya dan melelehkan budaya asal, sehingga seluruh imigran Amerika hanya memiliki satu budaya baru yakni Amerika, walaupun diakui bahwa monokultur mereka itu lebih diwarnai oleh white Anglo Saxon Protestant (WASP) bagai kultur imigran kulit putih berasal dari Eropa. (TIM ANPI,.2008:7)

Ketika komposisi etnis Amerika kian beragam dan budaya mereka kian majemuk, maka teori melting pot kemudian dikritik dan muncul teori baru yang populer dengan nama salad bowe. Teori ini sebagai teori alternatif dipopulerkan oleh Horace Kallen (Nurani Soyomukti.http://www.esaipolitiknurani.blogspot.com). Berbeda dengan melting pot yang melelehkan budaya asal dalam membangun budaya baru yang dibangun dalam keragaman, Teori salad bowl atau teori goda-gado tidak menghilangkan budaya asal, tapi sebaliknya kultur-kultur lain di luar diakomodir dengan baik dan masing-masing memberikan kontribusi untuk membangun budaya Amerika, sebagai sebuah budaya nasional. Pada akhirnya, interaksi kultural antara berbagai etnis tetap memerlukan ruang gerak yang leluasa, sehingga dikembangkan teori gerak yang pluralis, yang membagi ruang pergerakan budaya menjadi dua, yakni ruang publik untuk seluruh etnis mengarikulasikan budaya politik mereka. Dalam konteks ini, mereka homogen dalam sebuah tatanan budaya Amerika. Akan tetapi, mereka juga mempunyai ruang private yang di dalamnya mereka mengekspresikan budaya etnisitas secara leluasa. (TIM ANPI, 2007:8)

Multikulturalisme secara etimologis marak di gunakan pada tahun 1950-an di Kanada. Menurut Longer Oxford Dictionary istilah 'multiculturalism'merupakan deviasi dari kata 'multicultural'dengan menyetir kalimat dari surat kabar Kanada, Montreal Times yang menggambarkan masyarakat Montreal sebagai masyarakat 'multicultural'dan 'multi-lingual'. (Muheamin el-Ma'hady, 2004: 4) Namun secara gerakan,baru sekitar tahun 1970-an multikutarlisme muncul pertama kali di Kanada dan Australia, kemudian di Amerika Serikat, Inggris, Jerman dan lainnya. (Mun'im A. Sirry, 2002: 1)

Sedangkan menurut Tilaar, pendidikan multikultur berawal dari berkembangnya gagasan dan kesadaran tetang 'interkulturalisme' seusai Perang Dunia II. Kemunculan gagasan dan kesadaran 'interkulturalisme' ini selain terkait dengan perkembangan politik internasional menyangkut HAM, kemerdekaan dari kolonialisme, juga karena meningkatnya pluralitas di negara-negara baru merdeka bermigrasi Amerika dan Eropa. (Hero Nugroho: 2008)

Di negara-negara bekas jajahan muncullah gerakan yang dapat kita sebut poskolonialisme yang melihat aib dari praktik-praktik kolonial yang membedakan harkat manusia. Ada bangsa penjajah, bangsa super, dan bangsa dijajah atau yang didominasi oleh bangsa lain. Termasuk dalam pandangan ini adalah supremasi kulit putih dan supremasi kebudayaan Barat. Timbul reaksi biner ini seperti munculnya gerakan orientalisme dan gerakan-gerakan poskolonialisme lainnya. Dinegara-negara maju termasuk bekas-bekas penjajah maupun negaranegara demokrasi seperti Amerika Serikat, terdapat tentangan terhadap praktik-praktik kehidupan demokratis. Di Amerika Serikat, kita kenal mengenai rasisme yang melahirkan manusia seperti Martin Luther King dan gerakan-gerakan menghapuskan rasisme dalam praktik kehidupan. Pemikiran-pemikiran ini merembas ke dalam dunia pendidikan.

Di Indonesia, pendidikan multikultural relatif baru dikenal sebagai suatu pendekatan yang di anggap lebih sesuai bagi masyarakat Indonesia yang heterogen, terlebih pada masa 
otonomi dan desentralisasi yang baru dilakukan. Pendidikan multikultural yang dikembangkan di Indonesia sejalan dengan pengembangan demokrasi yang dijalankan sebagai counter terhadap kebijakan desentralisasi dan otonomi daerah

\section{PENGERTIAN MULTIKULTURAL}

Istilah multikulturalisme menurut Parekh (1997:2001) sebagaimana dikemukakan oleh Saifuddin (2006:139) mencakup sedikitnya tiga unsur, yaitu (1)terkait dengan kebudayaan, (2) merujuk kepada pluralitas kebudayaan, dan (3)cara tertentu untuk merespon pluralitas tersebut. Dengan demikian, makamultikulturalisme adalah cara pandang kebudayaan yang diwujudkan secara konkret dalam kehidupa yang nyata.

Berkaitan dengan pendapat di atas, Lawrence A Blum, seorang profesor filsafat di University of Massachusetts di Amherst menawarkan definisimultikulturalisme sebagai berikut:Multikulturalisme meliputi sebuah pemahaman, penghargaan dan penilaian atas budaya seseorang, serta ebuah penghormatan dan keingintahuan tentang budaya etnis orang lain. Ia meliputi sebuah penilaian terhadap budaya-budaya orang lain, bukan dalam arti menyetujui seluruh aspek dari budaya-budaya tersebut, melainkan mencoba melihat bagaimana sebuah budaya yang asli dapat mengekspresikan nilai bagi anggota-anggotanya sendiri. (Blum, 2001:16)

Tuntutan pengembangan masyarakat multikultural tidak dapat dilepaskan dari kebutuhan warganegara. Memasuki abad ke-21, warganegara suatu bangsadihadapkan pada berbagai perubahan dan ketidakpastian seiring denganperkembangan konstelasi kehidupan dalam berbagai aspek, baik aspek politik,sosial, ekonomi, pendidikan, kebudayaan, dan sebagainya. Dalam kehidupan ini,perubahan merupakan suatu kaniscayaan karena tidak ada yang tetap kecuali perubahan itu sendiri. Perubahan merupakan bagian yang melekat dalam kehidupan manusia dan terjadi secara terus menerus. Dalam dimensi manusia, perubahan yang terjadi menyangkut perubahan yang berkaitan erat langsung atau tak langsung dengan pemikiran, sikap, dan tindakan manusia dalam lingkup global, memberi konteks terhadap pemikiran, sikap dan tindakan manusia.

Multikulturalisme adalah landasan budaya yang terkait dengan pencapaian civility (keadaban), yang amat esensial bagi terwujudnya demokrasi yang berkeadaban, dan keadaban yang demokratis (Azra, 2004). Laporan UNDP 2004 menyatakan, berbagai studi kasus dan analisis menunjukkan, demokrasi yang bertahan dan berkelanjutan umumnya terdapat di negaranegara yang memiliki pandangan multikultural dan kemudian menerapkan multikulturalisme dalam berbagai kebijakan.

Kebijakan-kebijakan responsif dan afirmatif sebagai bentuk "politics of recognition" yang menjadi dasar multikulturalisme memberikan insentif dalam penumbuhan dan penguatan perasaan "kesatuan dalam keragaman" (Hefner, 2007; 5 Azra, 2006). Lebih jauh, dalam kerangka itu, seluruh warganegara dapat menemukan ruang politik an institusional untuk mengidentifikasi diri mereka dengan negara-bangsa mereka sekaligus dengan dentitas-identitas cultural lainnya. Semua ini mendorong tumbuhnya "trust" secara bersama-sama dalam diri warganegara, sehingga memperkuat partisipasi mereka dalam proses-proses politik demokratis.

Semua ini merupakan faktor-faktor kunci dalam konsolidasi dan pendalaman demokrasi sehingga negara-bangsa mampu bertahan dan berkelanjutan. Yang tidak kurang pentingnya dalam membangun demokrasi multikultural adalah pengakuan atas kekurangan dan kelemahan yang pernah terjadi dalam upaya-upaya penguatan nation-building, seperti misalnya monokulturalisme.Kesalahan dan kelemahan itu pada gilirannya justru menjadi dasar dan 
justifikasi untuk membangun demokrasi multikultural yang dapat merupakan solusi efektif bagi penciptaan stabilitas politik dan harmoni sosial.

Terkait dengan pengembangan masyarakat dan demokrasi multikultural di atas, peran penting pendidikan menjadi tak terelakan. Dalam pandangan Azra (2006:153) pembentukan masyarakat multikultural Indonesia yang sehat tidak bisa secara taken for granted atau trial and error. Sebaliknya harus diupayakan secara sistematis, programatis, integrated dan berkesinambungan. Salah satu strategi penting itu adalah pendidikan multikultural yang diselenggarakan melalui seluruh lembaga pendidikan, baik formal maupun nonformal, dan bahkan informal di masyarakat.Secara sederhana, pendidikan multikultural didefinisikan Azra (2006:157) sebagai pendidikan untuk/atau tentang keragaman kebudayaan dalam meresponi perubahan demografis dan kultural lingkungan masyarakat tertentu atau bahkan dunia secara keseluruhan.

Menurut Irmawan Abdullah, dalam Husamah (Http://www. Icrp-online.org) multikulturalisme adalah faham yang menekankan pada kesederajatan dan kesetaraan budayabudaya lokal tanpa mengabaikan hak-hak dan eksistensi budaya yang ada. Dengan kata lain, penekanan utama multikultural adalah kesetaraan budaya. Sementara itu, Masdar Hilmy, (2003:245) mengatakan multikulturalisme adalah sebuah konsep di mana sebuah komunitas dalam konteks kebangsaan dapat mengakui keberagaman, perbedaan dan kemajemukan budaya baik ras, suku dan agama. Sebuah konsep yang memberikan pemahaman bahwa, sebuah bangsa yang plural atau majemuk atau bangsa yang dipenuhi dengan budaya-budaya yang beragam. Dan bangsa multikultural adalah bangsa yang kelompok-kelompok etnik atau budaya yang ada dapat hidup berdampingan secara damai dalam prinsip co-existensi yang ditandai oleh kesediaan untuk menghormati budaya lain.

Gagasan multikulturalisme yang dinilai mengakomodir kesetaraan dalam perbedaan merupakan sebuah konsep yang mampu meredam konflik vertikal dan horizontal dalam masyarakat yang heterogen, (Ki Supriyoko.http://www.kompas-opini.com) di mana tuntutan akan pengakuan atas eksistensi dan keunikan budaya kelompok etnis sangat lumrah terjadi. Masyarakat multikultural digambarkan mampu memberikan ruang yang luas bagi berbagai identitas kelompok untuk melaksanakan kehidupan secara otonom. Dengan demikian akan tercipta suatu sistem budaya (cultural system) dan tatanan sosial yang mapan dalam kehidupan masyarakat yang akan menjadi pilar kedamaian sebuah bangsa.

Menurut Parsudi Suparlan (TIM ANPI. 2008:8) sosiolog dari Universitas Indonesia, menjelaskan bahwa multikulturalisme adalah sebuah ideologi yang mengakui dan mengagungkan perbedaan dalam kesederajatan baik secara individual maupun secara kebudayaan. Oleh karena itu konsep multikulturalisme tidaklah dapat disamakan dengan konsep keanekaragaman secara sukubangsa (etnis) atau kebudayaan suku bangsa yang menjadi ciri khas masyarakat majemuk, karena multikulturalisme menekankan keanekaragaman kebudayaan dalam kesederajatan.

Dengan gagasan di atas akan terbentuk sebuah persepsi yang hidup dalam masyarakat bahwa budaya bukanlah suatu kemutlakan yang harus dipertahankan. Budaya akan difahami sebagai sebuah gerak (move). Dalam arti, budaya tumbuh dan berkembang seiring dengan berkembangnya masyarakat itu sendiri yang tentunya dipengaruhi oleh faktor eksternal yang mengelilingi kehidupan.

Adanya sikap anarkis berkaitan dengan tuntutan pengakuan terhadap identitas etnis atau diri pada umumnya disebabkan oleh tidak adanya kesadaran semacam itu. Kebudayaan yang tumbuh dalam sebuah komunitas dipandang sebagai sebuah kemutlakan yang harus diakui dan 
diagungkan keberadaannya. Parsudi Suparlan dalam Sy. Ibrahim Al-Qadrie (2007:8) mengartikan lebih spesifik kepada 'masyarakat multikulturalisme Indonesia' (Indonesian multiculral Society) adalah 'masyarakat yang bercorak majemuk' (plural society) dalam corak masyarakat Indonesia yang 'Bhenika Tunggal Ika' bukan lagi keanekaragaman kelompok etnis atau suku bangsa, agama dan budaya (dalam bentuk fisik apa adanya), melainkan keanekaragaman kebudayaan yang ada di dalam masyarakat Indonesia. Jadi multikulturalisme berkaitan dengan pengertian, penerimaan dan penghargaan terhadap perbedaan dalam kesederajatan baik individu maupun kelompok yang berkaitan dengan pendapat, agama, ide, bahasa, tradisi, adat istiadat, dan unsur-unsur nilai budaya lainnya.

Dari beberapa pengetian yang diberikan oleh para ahli di atas, terdapat pengertian yang mendunia, yaitu pengertian multikulturalisme sebagai pandangan dunia yang kemudian di wujudkan ke dalam politic of recognition. Hal seperti itu disampaikan oleh Parek dalam bukunya National Cultural and Multiculturalisme, (Syamsul Arifin, 2007: 9) yang secara jelas membedakan lima macam multikulturalisme, sebagai berikut;

a. Multikulturalisme isolasionis yang mengacu kepada masyarakat di mana berbagai kelompok kultural menjalankan hidup secara otonom dan terlibat dalam interaksi satu sama lain.

b. Multikulturalisme akomodatif, yakni masyarakat plural yang memiliki kultural kaum minoritas.

c. Multikulturalisme otonomis, yakni masyarakat plural yang dimana kelompok-kelompok kultural utama berusaha mewujudkan kesetaraan (equality) dengan budaya dominan yang mengharapkan kehidupan otonom dalam kerangka politik yang secara kolektif dapat diterima. Concern pokok kelompok-kelompok kultural terakhir ini adalah untuk mempertahankan cara hidup mereka, yang memiliki hak yang sama dengan kelompok dominan dan berusaha menciptakan suatu masyarakat dimana semua kelompok dapat eksis sebagai mitra sejajar.

d. Multikulturalisme kritikal atau interaktif, yakni masyarakat plural dimana kelompokkelompok tidak terlalu concern dengan kehidupan kultural otonom, tetapi lebih menuntut penciptaan kultur kolektif yang mencerminkan dan menegaskan perspektif-perspektif distingtif mereka.

e. Multikulturalisme kosmopolitan, yakni paham yang berusaha menghapuskan batas-batas kultur sama sekali untuk menciptakan sebuah masyarakat di mana setiap individu tidak lagi terikat oleh kelompok budaya tertentu.

Dari beberpa pengertian di atas, ada benang merah yang dijadikan pijakan, yaitu bahwa hak yang paling utama dari makna dan pemahaman multikulturalisme adalah kesejajaran. Masingmasing budaya dari manusia atau kelompok etnis harus diposisikan sejajar dan setara. Tidak ada yang lebih tinggi dan tidak ada yang lebih dominan. Semua kebudayaan pada dasarnya mempunyai kearifan-kearifan tersebut tidak dapat dinilai deri segi positif negatif dan tidak dapat dijelaskan melalui kaca mata kebudayaan lain.

\section{KONSEP-KONSEP MULTIKULTURALISME}

Upaya membangun Indonesia yang multikultural hanya dapat terwujud apabila; 1) Konsep multikultural menyebar luas dan dipahami pentingnya bagi bangsa Indonesia. Serta adanya keinginan bangsa pada level nasional maupun lokal untuk mengadopsi dan menjadikannya 
sebagai pedoman dalm kehidupannya; 2) kesamaan pemahaman di antara para ahli mengenai multikultural dan membangun konsep-konsep yang mendukung; dan 3) upaya-upaya yang harus dilakukan dalam mewujudkan cita-cita ini (Anita Lie.http://www.kompas-cetak/opini)

Konsep multikultural tidaklah dapat disamakan dengan konsep keanekaragaman secara suku bangsa atau kebudayaan suku bangsa yang menjadi ciri masyarakat majemuk. Karena multikulturalisme menekankan pada keanekaragaman kebudayaan-kebudayaan dalam kesederajatan. Multikulturalisme juga mengulas berbagai permasalahan yang mendukung ideologi ini, yakni politik dan demokrasi, keadilan dan penegakan hukum, kesempatan kerja dan berusaha, hak asasi manusia, hak budaya komunitas dan golongan minoritas serta berbagai konsep lainnya yang lebih relevan. Sama halnya dengan Blum (Achmad Fendiyani Saifuddin.http://www.kompas-cetak.com) mengatakan miltikulturalisme meliputi sebuah pemahaman, penghargaan dan penilaian atas seseorang dan sebuah penghormatan dan keingintahuan tentang budaya etnis orang lain. Ia meliputi sebuah penilaian terhadap kebudayaankebudayaan orang lain, bukan dalam arti menyetujui seluruh aspek dari kebudayaankebudayaantersebut, melainkan mencoba melihat bagaimana kebudayaan tertentu dapat mengekspresikan nilai bagi anggota-anggota sendiri.

Sedangkan Abdulah Faqih (http://abdullahfaqih.multiplay .com/ journal.com) menitikberatkan multikultural pada proses transaksi oleh anggota masyarakat untuk mengekspresikan pandangan dunia mereka yang berbeda untuk menuju ke arah kebaruan kultural. Kata multikultural menjadi pengertian yang sangat luas, tergantung dari konteks pendefinisian dan manfaat apa yang diharapkan dari pendefinisian tersebut. Yang jelas dalam kebudayaan multikultural setiap individu mempunyai kemampuan berinteraksi dan bertransaksi meskipun latar belakang kultur masing-masing berbeda, karena sifat manusia antara lain; akomodatif, asisiatif, adaptabel, fleksibel, dan kemauan untuk saling berbagi.

Pandangan ini mengisyaratkan bahwa keberagaman kultur mengandung unsur jamak dan dengan nilai-nilai kearifan. Dalam kontek membangun tatanan sosial yang kokoh, maka nilai-nilai kearifan itu, dapat dijadikan sebagai sumbu pengikat dalam berinteraksi dan bersosialisai antar individu atau kelompok sosial. Hanya dengan mempersempit perselisihan budaya yang tidak kondusif, maka siklus kehidupan sosial masyarakat yang majemuk akan terwujud dalam prinsipprinsip dasar yang bisa saling menghargai, menghormati dan menjaga satu dengan yang lainnya.

Menurut Musa Asy'arie (http://www.uin-suka.info/sukapressonline) memperkenalkan paradigma multikultural pada anak dapat dilakukan melalui dua cara; Yang pertama adalah menyampaikan pesan-pesan tentang multikulturalisme dengan memberikan contoh kehidupan sehari-hari, dan kedua secara tidak langsung, yaitu dengan menyampaikan cerita yang berisi pesan tentang multikultural melalui dongeng, legenda, dan fabel.

Dalam penelitian Ernie Isis Aisyah Amini (2005:121) mengatakan bahwa penilaian dan argumentasi yang kontekstual sangat dibutuhkan dalam membangun paradigma multikultural. Tentu saja diperlukan batuan dalam penjelasan tentang pengakuan adanya perbedaan yang melingkupi setiap karakter dalam fabel. Kesepakatan yang terjadi, serta akibat buruk yang muncul kalau homogenitas dipaksakan menjadi penyelesaian akhir. Itu sangat membantu terbentuknya pemahaman tentang paradigma multikultural pada diri anak.

Untuk itu diperlukan suatu strategi yang mampu menjembatani hambatan-hambatan untuk berinteraksi dalam masyarakat multikultural, yakni melalui lembaga pendidikan, diharapkan dapat menjadi alternatif pemecahan yang berfungsi mentransformasikan nilai-nilai multikultural 
pada anak bangsa. Dengan asumsi bahwa setiap orang membutuhkan hubungan sosial dengan orang lain dan mereka saling berinteraksi demi tercapainya kebutuhan sosial mereka dan keputusan yang melatarbelakanginya. Sekolah adalah tempat pembelajaran bagi siswa dari berbagai kultur yang berbeda-beda melalui proses belajar mengajar, melahirkan tingkah laku sosial, menyepakati norma dan nilai bersama membangun struktur kelembagaan.

Apa yang menjadi harapan pendidikan multikulturalisme tersebut di atas memang tidak mudah untuk diapliksikan, sebab harus diakui bahwa secara psikologis hidup seseorang seperti diistilahkan Purwasito, ahli komunikasi sosial budaya, (dalam Hamid Hasan: 2008) yakni penyakit sosial yang menjangkiti dan menggerogoti nasionalisme individu yang disebut "Hamba Budaya" yang merupakan sikap apriori dan apatis dari suatu komunitas etnis, agama dan ras tertentu dengan komunitas etnis, agama, dan ras yang lain.

Mengacu pada pandangan dan konsep di atas, maka multikulturalisme mempunyai makna dan fungsi yang tepat. Untuk itulah maka konsep tersebut menjadi penting dikembangkan dan diinternalisasikan dalam proses transformasi nilai-nilai bagi masyarakat bangsa yang beragam. Prinsip-prinsip konsep dasar multikultural yang mengakui dan menghargai keberagaman, akan sangat membantu bagi terjadinya perubahan format prilaku sosial yang kondusif dan menjanjikan di tengah kehidupan masyarakat yang majemuk.

\section{PENDIDIKAN MULTIKULTURAL}

Sebagai sebuah ide, pendidikan multikultural dibahas dan diwacanakan pertama kali di Amerika dan negara-negara Eropa Barat pada tahun 1960-an oleh gerakan yang menuntut diperhatikannya hak-hak sipil (civil right movement). Tujuan utama dari gerakan ini adalah untuk mengurangi praktik driskriminasi di tempat-tempat publik, di rumah, di tempat-tempat kerja, dan di lembaga-lembaga pendidikan, yang dilakukan oleh kelompok mayoritas terhadap kelompok minoritas.Selama itu, di Amerika dan negara-negara Eropa Barat hanya dikenal adanya satu kebudayaan, yaitu kebudayaan kulit putih yang Kristen. Golongan golongan lainnya yang ada dalam masyarakat-masyarakat tersebut dikelompokkan sebagai minoritas dengan pembatasan hakhak mereka (Pardi Suparlan, 2002:2-3).

Gerakan hak-hak sipil ini, menurut James A. Bank (1989: 4-5), berimplikasi pada dunia pendidikan, dengan munculnya beberapa tuntutan untuk melakukan reformasi kurikulum pendidikan yang sarat dengan diskriminasi. Pada awal tahun 1970-an muncullah sejumlah kursus dan program pendidikan yang menekankan pada aspek-aspek yang berhubungan dengan etnik dan keragaman budaya (cultural diversity).

Alasan lain yang melatarbelakangi adanya pendidikan multikultural adalah keberadaan masyarakat dengan individu-individu yang beragam latar belakang bahasa dan kebangsaan (nationality), suku (race or etnicity), agama (religion), gender, dan kelas sosial (social class). Keragaman latar belakang individu dalam masyarakat tersebut berimplikasi pada keragaman latar belakang peserta didik

dalam suatu lembaga pendidikan (Bank, 1989: 14). Dalam konteks Indonesia, peserta didik di berbagai lembaga pendidikan diasumsikan juga terdiri dari peserta didik yang memiliki beragam latar belakang agama, etnik, bahasa, dan budaya. Asumsi ini dibangun berdasarkan pada data bahwa di Indonesia terdapat 250 kelompok suku, 250 lebih bahasa lokal (lingua francka), 13.000 pulau, dan 5 agama resmi (Leo Suryadinata, dkk., 2003: 30, 71, 104, dan 179). Paling tidak keragaman latar belakang siswa di lembaga-lembaga pendidikan di Indonesia terdapat pada 
paham keagamaan, afiliasi politik, tingkat sosial ekonomi, adat istiadat, jenis kelamin, dan asal daerahnya (perkotaan atau pedesaan).

Hal lain yang melatarbelakangi adanya pendidikan multikultural adalah adanya tiga teori sosial yang dapat menjelaskan hubungan antar individu dalam masyarakat dengan beragam latar belakang agama, etnik, bahasa, dan budaya. Menurut Ricardo L. Garcia (1982: 37-42) ketiga teori sosial tersebut adalah: (1) Melting Pot I: Anglo Conformity, (2) Melting Pot II: Ethnic Synthesis, dan (3) Cultural Pluralism: Mosaic Analogy. Ketiga teori tersebut populer dengan sebutan teori masyarakat majmuk (communal theory).

Teori pertama, Melting Pot I: Anglo Conformity, berpandangan bahwa masyarakat yang terdiri dari individu-individu yang beragam latar belakang seperti agama, etnik, bahasa, dan budaya harus disatukan ke dalam satu wadah yang paling dominan. Teori ini melihat individu dalam masyarakat secara hirarkis, yaitu kelompok mayoritas dan minoritas. Bila mayoritas individu dalam suatu masyarakat adalah pemeluk agama Islam, maka individu lain yang memeluk agama non-Islam harus melebur ke dalam Islam. Bila yang mendominasi suatu masyarakat adalah individu yang beretnik Jawa, maka individu lain yang beretnik non-Jawa harus mencair ke dalam etnik Jawa, dan demikian seterusnya. Teori ini hanya memberikan peluang kepada kelompok mayoritas untuk menunjukkan identitasnya. Sebaliknya, kelompok minoritas sama sekali tidak memperoleh hak untuk mengekspresikan identitasnya. Identitas di sini bisa berupa agama, etnik, bahasa, dan budaya.Teori ini tampak sangat tidak demokratis.

Karena teori pertama tidak demokratis, maka muncullah teori kedua, yaitu Melting Pot II: Ethnic Synthesis. Teori yang dipopulerkan oleh Israel Zangwill ini memandang bahwa individuindividu dalam suatu masyarakat yang beragam latar belakangnya, disatukan ke dalam satu wadah, dan selanjutnya membentuk wadah baru, dengan memasukkan sebagian unsur budaya yang dimiliki oleh masingmasing individu dalam masyarakat tersebut. Identitas agama, etnik, bahasa, dan budaya asli para anggotanya melebur menjadi identitas yang baru, sehingga identitas lamanya menjadi hilang. Bila dalam suatu masyarakat terdapat individuindividu yang beretnik Jawa, Sunda, dan Batak, misalnya, maka identitas asli dari ketiga etnik tersebut menjadi hilang, selanjutnya membentuk identitas baru. Islam Jawa di kraton dan masyarakat sekitarnya yang merupakan perpaduan antara nilainilai Islam dan nilai-nilai kejawen adalah salah satu contohnya. Teori ini belum sepenuhnya demokratis, karena hanya mengambil sebagian unsur budaya asli individu dalam masyarakat, dan membuang sebagian unsur budaya yang lain.

Mengingat teori kedua belum sepenuhnya demokratis, maka muncullah teori ketiga, yaitu Cultural Pluralism: Mosaic Analogy.Teori yang dikembangkan oleh Berkson ini berpandangan bahwa masyarakat yang terdiri dari individuindividu yang beragam latar belakang agama, etnik, bahasa, dan budaya, memiliki hak untuk mengekspresikan identitas budayanya secara demokratis. Teori ini sama sekali tidak meminggirkan identitas budaya tertentu, termasuk identitas budaya kelompok minoritas sekalipun. Bila dalam suatu masyarakat terdapat individu pemeluk agama Islam, Katholik, Protestan, Hindu, Budha, dan Konghucu, maka semua pemeluk agama diberi peluang untuk mengekspresikan identitas keagamaannya masing-masing. Bila individu dalam suatu masyarakat berlatar belakang budaya Jawa, Madura, Betawi, dan Ambon, misalnya, maka masing-masing individu berhak menunjukkan identitas budayanya, bahkan diizinkan untuk mengembangkannya. Masyarakat yang menganut teori ini, terdiri dari individu yang sangat pluralistik, sehingga masingmasing identitas individu dan kelompok dapat hidup dan membentuk mosaik yang indah. 
Dari ketiga teori komunal di atas, teori ketigalah yang dijadikan dasar oleh pendidikan multikultural, yaitu teori Cultural Pluralism: Mosaic Analogy.Untuk konteks Indoneisa, teori ini sejalan dengan semboyan negara Indonesia, Bbinneka Tunggal Ika.Secara normatif, semboyan tersebut memberi peluang kepada semua bangsa Indonesia untuk mengekspresikan identitas bahasa, etnik, budaya, dan agama masing-masing, dan bahkan diizinkan untuk mengembangkannya.

Tentang definisi pendidikan multikultural ada baiknya dikutip Lawrence J. Saha. Menurutnya, pendidikan multikultural dapat dipahami sebagai proses atau strategi pendidikan yang melibatkan lebih dari satu budaya, yang ditunjukkan melalui kebangsaan, bahasa, etnik, atau kriteria rasial. Pendidikan multicultural dapat berlangsung dalam setting pendidikan formal atau informal, langsung atau tidak langsung. Pendidikan multikultural diarahkan untuk mewujudkan kesadaran, toleransi, pemahaman, dan pengetahuan yang mempertimbangkan perbedaan kultural, dan juga perbedaan dan persamaan antar budaya dan kaitannya dengan pandangan dunia, konsep, nilai, keyakinan, dan sikap (Lawrence J. Saha, 1997: 348).

Definisi lain yang relevan untuk dikutip di sini adalah pendapat James A. Bank. Menurutnya, pendidikan multikultural adalah konsep atau ide sebagai suatu rangkaian kepercayaan (set of believe) dan penjelasan yang mengakui dan menilai pentingnya keragaman budaya dan etnis dalam membentuk gaya hidup, pengalaman sosial, identitas pribadi dan kesempatan-kesempatan pendidikan dari individu, kelompok maupun negara (James A. Bank, 2001: 28). Pendidikan itu sangat diperlukan terutama oleh negara demokrasi baru seperti Indonesia, untuk melakukan rekontruksi sosial dengan mengembangkan civic skill, yakni keterampilan menjadi warga dari masyarakat demokratis yang di antaranya mampu bersikap toleran dan mengakomodasi berbagai jenis perbedaan untuk kesejahteraan bersama.

Pendidikan multikultural dapat dilihat dari 3 (tiga) aspek: konsep, gerakan, dan proses (James A. Bank, 1989: 2-3). Dari aspek konsepnya, pendidikan multikultural dipahami sebagai ide yang memandang semua siswa tanpa memperhatikan gender dan kelas sosial mereka, etnik mereka, ras mereka, dan atau karakteristik-karakteristik kultural lainnya memiliki kesempatan yang sama untuk belajar di kelas. Dari aspek gerakannya, pendidikan multikultural didefinisikan sebagai usaha untuk mengubah sekolah-sekolah dan institusiinstitusi pendidikan sehingga siswa dari semua kelas sosial, gender, ras, dan kelompok-kelompok kultural memiliki kesempatan yang sama untuk belajar. Perubahan yang dilakukan tidak hanya terbatas pada kurikulum, tetapi juga aspek lain seperti metode, strategi, manajemen pembelajaran, dan lingkungan sekolah. Dari aspek prosesnya, pendidikan multikultural dapat dipahami sebagai proses untuk mencapai tujuan agar kesetaraan pendidikan dapat dicapai oleh semua siswa. Kesetaraan pendidikan, seperti kemerdekaan dan keadilan tidak mudah dicapai, karena itu proses ini harus berlangsung terusmenerus.

Sementara itu, tujuan pendidikan multikultural dapat dibedakan menjadi 3 (tiga) macam tujuan, yaitu: tujuan yang berkaitan dengan sikap, pengetahuan, dan pembelajaran (Lawrence J. Saha, 1997: 349). Tujuan pendidikan multikultural yang berkaitan dengan aspek sikap (attitudinal goals) adalah untuk mengembangkan kesadaran dan kepekaan kultural, toleransi kultural, penghargaan terhadap identitas kultural, sikap responsive terhadap budaya, keterampilan untuk menghindari dan meresolusi konflik. Tujuan pendidikan multikultural yang berkaitan dengan aspek pengetahuan (cognitive goals) adalah untuk memperoleh pengetahuan tentang bahasa dan budaya orang lain, dan kemampuan untuk menganalisis dan menerjemahkan perilaku kultural, 
dan pengetahuan tentang kesadaran perspektif kultural. Sedangkan tujuan pendidikan multikultural yang berkaitan dengan pembelajaran (instructional goals) adalah untuk memperbaiki distorsi, stereotip, dan kesalahpahaman tentang kelompok etnik dalam buku teks dan media pembelajaran; memberikan berbagai strategi untuk mengarahkan perbedaan di depan orang, memberikan alatalat konseptual untuk komunikasi antar budaya; mengembangkan keterampilan interpersonal; memberikan teknikteknik evaluasi; membantu klarifikasi nilai; dan menjelaskan dinamika kultural.

Secara sederhana pendidikan multikultural dapat didefenisikan sebagai pendidikan untuk/tentang keragaman kebudayaan dalam merespon perubahan demografis dan kultural lingkungan masyarakat tertantu atau bahkan dunia secara keseluruhan. (M. Amin Abdullah, 2005: 6). Hal ini sejalan dengan pendapat Paulo Freire, (dalam Siti Martiningsih. 2004: 23) pendidikan bukan merupakan "menara gading" yang berusaha menjauhi realitas sosial dan budaya.

Pendidikan multikulturalisme merupakan respon terhadap perkembangan keragaman populasi sekolah, sebagai mana tuntutan persamaan hak bagi setiap kelompok. Dalam dimensi lain, pendidikan multikulturalisme merupakan pengembangan kurikulum dan aktivitas pendidikan untuk memasuki berbagai pandangan, sejarah, prestasi dan perhatian terhadap yang lain. Sedangkan secara luas pendidikan multikultural itu mencakup seluruh siswa tanpa membedakan kelompok-kelompoknya seperti gender, etnik, ras, budaya, strata sosial, dan agama.

Selanjutnya James Banks, dalam Muhaemin el-Ma'hady, (bttp:// wnw.pendidikan.network.com), menjelaskan bahwa pendidikan multikultural memiliki lima dimensi yang saling berkaitan:

1) Content integration, mengintegrasikan berbagai budaya dan kelompok untuk mengilustrasikan konsep mendasar, generalisasi dan teori dalam mata pelajaran/ disiplin ilmu.

2) The Knowledge Construction Process, membawa siswa utuk memahami impliksi budaya ke dalam sebuah mata pelajaran (disiplin)

3) An Equity Pedagogy, menyesuaikan metode pengajaran dengan cara belajar siswa dalam rangka memfasilitasi prestasi siswa yang beragam baik dari segi ras, budaya ataupun sosial.

4) Prejudice Reduction, mengidentifikasi karakteristik ras siswa dan menentukan metode pengajaran mereka.

5) Melatih kelompok untuk berprestasi dalam kegiatan olehraga, berinteraksi dengan seluruh staff dan siswa berbeda etnis dan ras dalam upaya menciptakan akademik.

Dalam aktifitas pendidikan manapun, peserta didik merupakan sasaran (obyek) dan sekaligus sebagai subyek pendidikan. Oleh sebab itu, dalam memahami hakikat peserta didik, para pendidik perlu di lengkapi dengan pemahaman tentang ciri-ciri umum peserta didik, setidaknya secara umum peserta didik memiliki lima ciri yaitu; (Saekhan Muchith, 2008: 84)

1) Peserta didik dalam keadaan sedang berdaya, maksudnya ia dalam keadaan berdaya untuk menggunakan kemampuan, kemaun dan sebagainya.

2) Mempunyai keinginan untuk berkembang ke arah dewasa.

3) Peserta didik mempunyai latar belakang yang berbeda.

4) Peserta didik melakukan penjelajahan terhadap alam sekitar dengan potensi-potensi dasar yang dimiliki secara individu.

Mengenai fokus pendidikan multikultural, Tilaar (dalam M. Ainul Yaqin. 2007) mengungkapkan bahwa dalam program pendidikan multikultural, fokus tidak lagi diarahkan semata-mata kepada kelompok rasial, agama, dan kultural dominan atau mainstream. Fokus 
seperti ini pernah menjadi tekanan pada pendidikan interkultural yang menekankan peningkatan pemahaman dan tolerasi individu-individu yang berasal dari kelompok minoritas terhadap budaya mainstream yang dominan, yang pada akhirnya menyebabkan orang-orang dari kelompok minoritas terintegrasi ke dalam masyarakat mainstream. Pendidikan multikultural sebanarnya merupakan sikap "peduli" dan mau mengerti (difference), atau 'politic of recgnition'politik pengakuan terhadap orang-orang dari kelompok minoritas. (M. Zainuddin. http://www. uin.malang. co.id)

Dalam koteks itu, pendidikan multikultural melihat masyarakat secara lebih luas. Berdasarkan pendangan dasar bahwa sikap 'indifference'dan 'Non-Recognitian' tidak hanya berakar dari ketimpangan struktural rasial tetapi, paradigma pendidikan multikultural mencakup subyeksubyek mengenai ketidakadilan, kemiskinan, penindasan, dan latar belakangan kelompokkelompok minoritas dalam berbagai bidang: sosial, budaya, ekonomi, pendidikan dan lain sebagainya. Paradigman seperti ini akan mendorong tumbuhnya kajian-kajian tentang 'etthic studies' untuk kemudian menemukan tempatnya dalam kurikulum pendidikan sejak dari tingkat dasar ini adalah untuk mencapai pemberdayaan (empowerment) bagi kelompok-kelompok monoritas dan mayoritas. (Mochtar Buchori. http://www. kompas-cetak.opini)

Istilah "pendidikan multikultural" dapat digunakan baik pada tingkat deskriminatif maupun normatif, yang menggambarkan isu-isu dan masalah-masalah pendidikan yang berkaitan dengan masyarakat multikultural. Lebih jauh ia juga mencakup pengertian tetang pertimbangan terhadap kebijakan-kebijakan danstrategis-strategis ini.Oleh karenanya, kurikulum pendidikan multikultural mestilah mencakup subyek-subyek seperti: toleransi, tema-tema tentang perbedaan ethno-kultural dan agama; bahaya diskriminasi; penyelesaian konflik dan mediasi; HAM; demokrasi, dan pluralitas, kemanusian universal dan subyek-subyek lain yang relevan.

Dalam konteks teoritis, belajar dari metode-metode pendidikan multikultural yang pernah ada sedang dikembangkan oleh negara-negara maju, dikenal empat pendekatan, yaitu pertama, pendidikan mengenai perbedaan-perbedaan kebudayaan atau pemahaman kebudayaan. Kedua, pendidikan bagi pluralisme kebudayaan. Ketiga, pendidikan dwibudaya. Keempat, pendidikan multikultural sebagai pengalaman manusia. (M. Amin Abdullah.,2005).

Penting untuk diketahui juga, asumsi teoritik yang digunakan dalam mengembangkan pendidikan multikultur adalah sebagai berikut; (Ernie Isis Aisyah Amini, 2007:27)

Pertama, bahwa sekolah-sekolah belum sepenuhnya terpenuhi kebutuhan, baik itu kebutuhan sosial maupaun kebutuhan akademiknya. Substansi pembelajaran (materi pelajaran) disekolah belum sepenuhnya digali dari khasanah sosial dan kultural esensial (suku, agama, ras, tradisi, kearifan lokal dan sebagainya) masyarakat, khusus masyarakat minoritas termasuk yang miskin, yang tidak/kurang berpendidikan, maupun yang berspektif gender. Dikebanyakan masyarakat Indonesia, wanita sering memperoleh peran dan kedudukan tak adil dibandingkan pria. Perlakuan kurang adil dibandingkan pria., perlakuan kurang adil disebabkan oleh harapan masyarakat yang bersifat stereotip, akibatnya wanita menjadi subordinasi kaum pria. Konsekuensinya maka pendidikan mutikultural mengandung unsur-unsur keadilan gender, suku, agama, ras, maupun kelompok-kelompok minoritas. Pendidikan mutikultural dirancang sedemikian rupa sehingga menyediakan kesempatan untuk memperoleh dan menikmati pendidikan bermutu dan segregatip. (Hamid Hasan.,2006: 8)

Kedua, Bahwa lingkugan sosial pembelajar justru sering mengorbankan hampir semua jati diri pembelajar di sekolah. 
Ketiga, bahwa dengan semakin banyaknya, khotbah atau ceramah tentang nilai-nilai, demokrasi, kebebasan, keadilan, persamaan derajat dan sejinisnya, maka struktur sosial sekolah akan dapat mempromosikan nilai nilai serta prilaku yang baik dan ideal. Misalnya, sistem penjurusan dan kegiatan lomba sering memiliki dampak terbaik (counter produktive) terhadap nilai kerjasama, altruistik dan elitis. Sebaiknya struktur sekolah yang egaliterian sering menciptakan suasana konformitas, loyal, setia, taat dan sejenisnya, yang sesunggungnya membunuh sikap memberdayakan diri. Sepatutnya sekolah sebagai tempat pembelajaran bagi siswa dari berbagai kutur yang berbeda-beda, sebab melalui proses belajar mengajar melahirkan tingkah laku sosial, menyepakati norma dan nilai bersama membangun struktur kelembagaan.

Keempat, bahwa sekolah tidak dapat mengindari dari kegiatan mentransmisikan nilai kepada anak didik. Banyak nilai-nilai luhur ditransmisikan lewat kurikulum tersembunyi (bidden curriculum). Demikian pula anak didik diasumsi bersikap bebas, tidak ada beban psikologis dan merasa terdorong untuk bertanya atau mengkritisi nilai-nilai yang disodorkan kepadanya. Dalam asumsi ini terkandung sikap dan unsur kreatifitas, produktifitas dan kemandirian pada anak. (M. Saekhan Muchith, 2008: 92)

Kelima, sekolah memiliki kemampuan untuk beroprasi sendiri dalam mentransmisikan nilai-nilai luhur tersebut, maka dari itu sekolah hanya berfungsi sebagai utama adalah membantu siswa untuk dapat mengkonseptualisasikan dan mengaspirasikan sebuah masyarakat yang lebih baik. Pendidikan juga memiliki peran membantu siswa memperoleh pengetahuan, keterampilan, pemahaman yang memungkinkan perubahan-perubahan yang diperlukan. Pendidikan diasumsikan dapat meningkatkan kualitas sekolah bagi kepentingan siswa secara historis selalu dimarjinalisasikan.

Pendidikan multikultural (multicultural education) tidak persis sama dengan enkulturasi ganda (multiple enculturation). Sizemore membedakan antara pendidikan multikultural dengan enkulturasi ganda. Menurut Sizemore dalam Choirul Mahfud.(http://www.seputarindonesia.com.) enkulturasi lebih menekankan pada integrasi struktural, yang mengaburkan makna akulturasi dengan enkulturasi. Pendidikan multikultural menurutnya merupakan sebuah proses memperolehan pengetahuan untuk dapat mengontrol orang lain demi sebuah kehidupan (survival). Pendidikan multikultural sebenarnya merupakan sikap peduli dan mau mengerti (difference) atau 'politics of recognition', politik pengakuan terhadap orang-orang dari kelompok minoritas (Tylor et. al (1994) dalam Ernie Isis Aisyah Amini.

Secara operasional, pendidikan multikultural pada dasarnya adalah program pendidikan yang menyediakan sumber belajar yang jamak bagi pebelajar (multiple learning environments)dan yang sesuai dengan kebutuhan akademik maupun sosial anak didik.

Anderson dan Cusher (dalam Hasan: 2001) mengatakan bahwa multikultural adalah pendidikan keragaman kebudayaan. Definisi ini mengandung unsur yang lebih luas, meskipun demikian posisi kebudayaan masih sama yakni mencakup keragaman kebudayaan menjadi sesuatu yang dipelajari sebagai objek studi. Dengan kata lain keragaman kebudayaan menjadi materi pelajaran yang harus diperhatikan, khususnya bagi rencana pengembangan kurikulum. Pendidikan multikultural sebagai pengganti dari pendidikan interkultural, diharapkan dapat menumbuhkan sikap peduli dan mau mengerti atau adanya politik pengakuan terhadap kebudayaan kelompok manusia seperti; toleransi, perbedaan etno-kultural dan agama, diskriminasi, HAM, demokrasi dan pluralitas, kemanusiaan universal serta subyek-seubyek lain yang relevan. 
Menurut Farid Ari Fandi. (http://www.icrp-online.org) Inkorporasi pendidikan multikultural ke dalam program pendidikan memiliki harapan dan cita-cita sebagai berikut;

1) Pendidikan multikultural adalah pendidikan yang menghargai pluralisme budaya. Artinya, pluralisme budaya itu tidak hanya ditoleransi tetapi juga dirangkul dan keragaman pengalaman manusia itu diharapkan memberi kearifan. Pendidikan multikultural merupakan sebuah alternatif daripada membiarkan anak memperoleh sendiri pengalaman pluralisme budaya-sporadis dan fragmentaris. Cara seperti ini hanya akan menghasilkan distorsi dan inadekuasi.

2) Pendidikan multikultural secara eksplisit mengakui dan menyambut keragaman dari warisan etnik yang ditemukan dalam diri setiap orang yang disebut "orang Indonesia" dan oleh karena itu menolak pandangan bahwa sekolah harus berupaya mencairkan perbedaan kultural atau sebaiknya hanya mentoleransi pluralisme budaya.

3) Pendidikan multikultural tidak memaksa atau menolak anak karena identitas suku, agama, ras, golongan. Sebagian keluarga mungkin tidak dapat mengidentifikasi dengan pasti warisan etnik mereka, dan keluarga lain mungkin tidak tertarik untuk melakukan hal itu. Masih ada keluarga yang memiliki warisan campuran sehingga mengidentifikasi semacam ini menjadi kurang bermakna. Yang lain mengetahui warisan mereka akan tetapi tidak mau anak-anak mereka untuk membangun rasa identitas etnik yang kuat. Pendidikan multikultural mengakui kebutuhan dan manfaat anak untuk berbagi bersama (sharing) diversitas warisan etnik mereka.

4) Pendidikan multikultural mengakui pentingnya semua anak memiliki banyak kesempatan untuk berinteraksi secara positif dan personal dengan anak-anak dari berbagai latar belakang sosioekonomi dan warisan budaya.

5) Pendidikan multikultural memberikan setiap siswa kesempatan untuk membantu berkembangnya sense of self. Ini terutama bagi anak-anak yang secara ekonomi tidak beruntung dan apalagi berasal dari sebuah kelompok etnik yang relatif terisolasi atau yang memiliki sejarah penderitaan panjang akibat diskriminasi dan prasangka.

Tujuan menurut Saudi Patro. (1997: 116) program pendidikan multikultural adalah untuk membantu siswa: (1) Memahami latar belakang diri dan kelompok dalam masyarakat, (2) Menghormati dan mengapresiasi kebhinekaan budaya dan sosio-historis etnik, (3) Menyelesaikan sikap-sikap yang terlalu etnosentris dan penuh purbasangka, (4) Memahami faktor-faktor sosial, ekonomis, psikologis, dan historis yang menyebabkan terjadinya polarisasi etnik ketimpangan dan keterasingan etnik (5) Meningkatkan kemampuan menganalisis secara kritis masalah-masalah rutin dan isu melalui proses demokratis melalui sebuah visi tentang masyarakat yang lebih baik, adil dan bebas dan (6) Mengembangkan jati diri yang bermakna bagi semua orang.

Definisi dan tujuan pendidikan multikultural yang diajukan pada bagian terdahulu sesuai dengan asumsi-asumsi yang digunakan didepan tentang sebuah masyarakat plural (pluralistic society).Batasan tentang pendidikan multikultural lain umumnya mengandung asumsi implisit bahwa pluralisme kultural dapat ditingkatkan dalam konteks struktur sosial yang telah ada. Sedangkan definisi pendidikan multikultuaral yang diadopsi dari Suzuki dan Pramono dalam Levi Riansyah. (http://www.averroes.or.id/opini) didasarkan pada asumsi awal bahwa sekolah dapat memainkan peranan besar dalam mengubah struktur sosial sebuah masyarakat.Ini tidak berarti bahwa sekolah satu-satunya lembaga sosial yang dapat mengubah struktur sosial sebuah masyarakat, tetapi dalam pengertian ini bahwa sekolah dapat menjadi wahana atau menjadi sebuah alat bagi sebuah perubahan sosial dari masyarakat.Guru-guru dapat membantu siswanya 
mengkonseptualisasi dan menumbuhkan aspirasi tentang sebuah struktur sosial alternatif serta memungkinkan siswa memperoleh pengetahuan dan keterampilan untuk berubah. Definisi dan tujuan inilah yang akan dikembangkan menjadi sebuah program pendidikan multikultural pada sekolah-sekolah yang memiliki latar belakang dan kebhinekaan sosio-historis, budaya, ekonomi dan psikologi.

Pendidikan multikulturalisme dalam konteks Indonesia, penting untuk dikembangkan. Hal ini mengingat faktor kebhinekaan bangsa Indonesia, dan faktor-faktor lain yang menjadi pengalaman bangsa Indonesia. Terjadinya pristiwa disintegrasi sosial dan konflik selama ini, semakin perlu untuk di antisipasi secara tepat, dan hal yang paling memungkinkan adalah melalui program pendidikan multikulturalisme. Persoalannya kemudian adalah, kesungguhan dalam merumuskan pendidikan multikulturalisme dalam kontek Indonesia yang tepat semangat dan tepat tujuan. Itulah pentingnya untuk dilakukan banyak kajian atau penelitian, sehingga dapat memberikan gambaran dan bahkan acuan bagi kebutuhan lebih lanjut.

\section{KONSEP ISLAM TENTANG NILAI-NILAI MULTIKULTURAL}

Sebagai risalah profetik (Istilah "profetik sebagai salah satu kesadaran yang menggaris bawahi pentingnya seorang muslim untuk tidak larut dalam pengalaman keagamaan yang sifatnya personal dan hilang dari kefanaan, namun pengalaman mistik perjumpaan dengan Allah itu di teruskan ke bumi untuk melakukan perubahan social, budaya, politik, ekonomi, dan intelektual manusia. Teori ini pernah di populerkan oleh Muhammad Iqbal). Islam pada intinya adalah seruan pada semua umat manusia, termasuk mereka para pengikut agama-agama, menuju satu cita-cita bersama kesatuan manusia (unility of bumankind) tanpa membedakan ras, warna kulit, etnik, kebudayaan dan agama. Karena umat manusia tak ubahnya waktu, keduanya maju tak tertahan. Dan sama seperti tak ada jam tertentu yang mendapat kedudukan khusus, begitu pula tak ada satu pun orang, kelompok atau bangsa manapun yang dapat membanggakan diri sebagai diistimewakan Tuhan (the chosen people). (Thomas Koten. 2008) Ini dapat berarti bahwa dominasi ras dan diskriminasi atas nama apapun merupakan kekuatan antitas terhadap tauhid, dan karenanya harus dikecam sebagai kemusyrikan dan sekaligus kejahatan atas nama kemanusiaan (baca HAM). Pesan kesatuan ini secara tegas disinyalir al-Qur'an yang artinya:

Katakanlah: "Hai Abli Kitab, marilah (berpegang) kepada suatu kalimat (ketetapan) yang tidak ada perselisiban antara kami dan kamu, babwa tidak kita sembah kecuali Allab dan tidak kita persekutukan Dia dengan sesuatupun dan tidak (pula) sebagian kita menjadikan sebagian yang lain sebagai Tuban selain Allah." Jika mereka berpaling maka katakanlab kepada mereka: "Saksikanlah, babwa kami adalah orang-orang yang berserah diri (kepada Allab)." (Q.S Ali Imran: 64)

Sementara itu Zakaiyuddin Baidhawy (2005: 45) menterjemahkan ayat diatas adalah: "Katakanlah: wahai semua penganut agama (dan kebudayaan)! Bergegaslah menuju dialog dan perjumpaan multikultur (kalimatun sawa') antara kami dan kamu".

Dialog bukan semata percakapan bahkan juga dua pikiran dan hati mengenai persoalan bersama, dengan komitmen yang tujuan agar setiap pertisipan dapat belajar dari yang lain sehingga dapat berubah dan berkembang. Dialog merupakan pangkal pencerahan nurani dan akal pikiran (tanwir al-qulub wa al 'uqul) menuju kematangan cara beragama yang menghargai the otherness. (M. Zainuddin. 2008) Dengan demikian kalimatun sawa' adalah menyangkut cara manusia melakukan perjumpaan dengan dan memahami diri sendiri dan dunia lain pada tingkat terdalam, membuka kemungkinan-kemungkinan untuk menggali dan menggapai selekta makna 
fundamental kehidupan secara individu dan koleltif dengan berbagai dimensinya. (Ruslani. http://www.suarakarya-online.com/news)

Secara eksperimantal kalimatun sawa' tampil ke permukaan dan menjangkau perjumpaan antar dunia multikultur yang begitu luas. Ketika menusia hidup melalui perjumpaan agama-agama, seolah kita mendapatkan pengalaman antarkultur (intercultur experiences), seperti kita berjuang dengan pola-pola sejarah pertentangan berbagai pandangan dunia, seperti kita melibatkan secara kreatif kekuatan-kekuatan besar dalam kehidupan sipil dimana pertempuran idiologi dan kehidupan pribadi. Pengalaman multikultur ini membuat kita mempu bangkit dan sadar dengan perspektif baru yang lebih memadai. (Nasikun.http://www.psbps.org.com) Dengan demikian. Kalimatun sawa' bukan hanya mengakui pluralitas kehidupan. Ia adalah sebentuk manisfesto dan gerakan yang mendorong kemajemukan dan keragaman sebagai prinsip inti kehidupan dan mengukuhkan pandangan bahwa semua kelompok multikultur diperlukan secara setara dan bermartabat. (Abdul Munir Mulkan. 2005)

Penemuan sangat nyata atas pengalaman multikultural yang demikian intensif merupakan suatu keharusan dan kebutuhan yang tak terelakkan. Penemuan ini adalah dasar dan sumber utama diluar perbedaan dan keragaman pandangan dunia dan perspektif. Dengan memperolah akses pada sumber bagi seluruh kehupan kultural dan mengalaminya, menjadi sangat jelas bahwa umat manusia sedang berada di tengah-tengah tranformasi diri yang mendalam dan kematangan kemanusiaan.

Multikultur dipandang sebagai sunnatullah yang tidak akan pernah berubah sekali dan selamanya. Kerana merupakan kodrat Tuhan dan kenyataan yang tak terbantahkan, toleran terhadap pluralitas dan perbedaan menghendaki pula sikap saling memahami (mutual understanding) dan saling mengargai (mutual respect). (Komarrudin Hidayat. 2001) Hal ini juga di singgung dalam al-Qur'an yang artinya:

Hai manusia, sesunggubnya Kami jadikan dari kalian dari jenis laki-laki dan perempuan, dan menjadikan kalian berkelompok-kelompok dan berbangsa-bangsa, agar kalian saling memahami dan saling mengahargai. Sesungguhnya orang yang paling bermartabat di sisi Allab adalah mereka yang paling dapat memahami dan mengargai perbedaan dan antara kamu." (Q.S Al-Hujaraat: 13)

Ayat ini setidaknya mengandung tiga prinsip utama berkaitan dengan hidup dalam keragaman dan perbedaan. (Ngainun Naim dan Ahmad Sauqi. 2008:123) Pertama, prinsip plural dan usual. Yakni, kepercayaan dan praktek kehidupan bersama yang menandaskan kemejemukan sebagai sesuata yang lumrah dan tidak perlu diperdebatkan apalagi di pertentangkan. Keagaman cara berpikir dan cara bertindak umat manusia dalam konteks ruang dan waktu selalu dan selamanya akan terus eksis. Keberadaan-apakah dalam agama dan kebudayaan-selalu saja hadir memberi nuansa spektrum kehidupan yang tidak menonton, ia selalu dinamis san dialektis, dengan demikian, Islam tidak mengenal kejumudan dan dogmatisme.

Kedua, prinsip equal is usual. Ayat tersebut merupakan normatifitas bagi kesadaran baru umat manusia mengenai reaitas dunia plural. Kesadaran ini bukan hanya karena telah mampu melihat jumlah etnis dan bangsa yang sangat beragam di dunia ini.

Ketiga. Prinsip modesty in diversity (sahaja dalam keragaman). Bersikap dewasa dalam merespon keragaman menghendaki kebersahajaan. Yakni sikap moderat yang menjamin kearifan berpikir (opon mind)dan bertindak, Jauh dari fansatisme yang sering melegitimasi penggunaan 
instrument kekerasan dalam mencapai tujuan. (Ruslani. http://www.suarakaryaonline.com/news)

\section{PENDIDIKAN MULTIKULTURALISME DALAM PENDIDIKAN AGAMA ISLAM URGENSI DAN SIGNIFIKANSI}

Pendidikan Islam multikultur bukan Pendidikan multikukultural adalah suatu keniscayaan. Ia merupakan paradigma dan metode untuk mengawali potensi keragaman etnik dan kultural nusantara, dan mewadahinya dalam suatu manajemen konflik yang memadai. Pendidikan multikultur merupakan kearifan dalam merespon dan mengantisipasi dampak negatif globalisasi yang memaksakan homogenisasi dan hegomoni pola hidup. Ia juga menjembatan yang mengubungkan dunia multipolar dan multikultur yang mencoba direduksi isme dunia tunggal kedalam dua kutub saling berbenturan antara Barat-Timur dan Utara-selatan.

Sebagai mana Aung San Suu Kyi mengatakan "Tepatnya karena keragaman kultrul dunia, adalah suatu keharusan bagi semua bangsa dan masyarakat mencapai kata sepakat tentang nilai-nilai kemanusian fundamental yang akan bertindak sebagai faktor pemersatu umat. (Hardi Sujaie.2008)

Perubahana paradigma dalam pendidikan diyakini sebagai satu keharusan dalam rangka mempertimbangkan perkembangan kontemporer yang menggambarkan sofistikasi kehidupan. Kompleksitas tantangan kehidupan dan kehidupan era informasi dan globalisasi mondial telah membawa dunia pada satu global village, dimana proses homogenisasi kebudayaan disentero dunia tanpa kecuali. Food, fun, fashion (F3) adalah representasi yang paling mudah disaksikan berkaitan dengan pencitraan erat dengan pencitraan baru kebudayaan global.

Berangkat dari sinilah rasanya kita berpikir bahwa pendidikan konversional sudah tidak cukup memadai mewadahi kepentingan-kepentingan ruang dan waktu yang semakin tidak mengenal batas (borderless). Semua dapat dengan mudah dilampuai, jarak dapat diperpendek, waktu dapat dipersingkat. Pendidikan konvensional semakin terasa usang bukan hanya karena keterbatasan- keterbatasannya dalam mengejar laju pertumbuhan teknologi yang seringkali lebih cepat dari perikanan dan menimbulkan kejutan masa depan yang merangsek masa kini (future shock), bahkan juga karena paradigmanya sudah lapuk dimakan zaman. Tahapan dan cara yang keras namun kurang cerdas, startegi dan metode pembelajarannya yang menonton, kurang memberi kesempatan bagi kreatifitas dan inovasi siswa.(Wilfrerd Cantwell Smith, 2004: 212)

Pendidikan multikultur hadir sebagai jawaban atas "kelemahan-kelemahan" paradigma dan efistimologi pendidikan corak konvensional diatas. Pendidikan multikultur menghendaki suatu kerangka kerja dan cetek biru (fremework end bluprint) yang menjadi landasan kokoh dalam teori dan praktek. Perubahan utuma yang patut dikedepankan adalah menyangkut transformasi dari pengakuan atas persamaan hak (equality) menuju tegaknya keadilan (equity). (Wilson Lalengke.http://www.jil.com/opini)

Persamaan hak antara semua manusia memang sebuah kebutuhan dalam hidup, namun dalam persamaan boleh jadi masih ada kemungkinan terbentuknya ketidaksamaan kesempatan, sehingga perbedaan kesempatan itulah yang melahirkan ketidak adilan di mana-mana, penindasan dan mereka yang secara natural, struktural, maupun kultural. Dalam konteks ini, pendidikan multikultural perlu memperoleh penguatan jawaban atas pertanyaan pokok; apakah setiap siswa yang masuk sekolah memiliki kesempatan yang sama untuk membentuk dirinya secara penuh tanpa memandang ras, etnisitas, gender, agama, status sosial ekonomi, bahasa, kemampuan, dan 
serta indentitas sosial-kultural lainnya. Dan apakah kerja pendidikan yang tawarkan kepada siswa itu kontekstual dengan kepentingan masyarakat yang lebih luas sehingga mempertimbangkan sejarah penindasan yang di alami oleh berbagai individu dan kelompok.

Dengan dua pertanyaan penting ini, menjadi jelas bahwa pendidikan multikultural bukanlah suatu sistem yang di ciptakan untuk melanggengkan status quo kelas penguasa disatu sisi, dan melakukan peminggiran atas kelas tertindas di sisi lain. Pendidikan multikultur tidak dimaksudkan untuk mengokohkan kedudukan kaum kapital sebagai pemilik modal di balik megahnya insitusi-insitusi pendidikan. Dengan demikian juga sebaliknya, pendidik multikultur bukan memenangkan kelas marginal atas ruling elite; karena jika demikian halnya bearti ia bertentangan dengan paradigma sendiri (Heri Hamidi. 2006:91) Pendidikan multikultur harus memberi ruang yang sama atas berbagai kepentingan individu dan kelompok kultural, tanpa mendahulukan dan atau mengesampingkan hak-hak individu dan kelompok kepentingan.

Intinya, pendidikan multikultur perlu menjawab persoalan krusial seperti apakah tujuan pendidikannya dapat menghasilkan perubahan signifikan pada diri siswa (masyarakat dan bangsa pada umumnya) yang sangat plural di mana ketidakadilan-ketidakadilan telah menjadi berita aktual negeri ini.

Pada kenyataannya, kita pun merasakan bahwa pendidikan agama yang diebrikan di sekolah-sekolah pada umumnya tidak mampumenghidupkan semangat multikulturalisme yang baik, bahkan cendrung berlawanan. Akibatnya, konflik sosial sering kali diperkeras dalam ajaran pendidikan agama disekolah-sekolah tidak terkecuali madrasah tentunya dalam konteks penelitian ini buku teks pembelajaran pendidikan agama Islam dalam.

Hal itu membuat konflik mempunyai akar dalam keyakinan keagamaan yang fundamental, sehingga konflik sosial semakin sulit diatasi, karena dipahami sebagai bagian penggilan agama.

Pada kenyataannya menunjukan bahwa pendidikan agama masih diajarkan dengan cara menafikkan hak hidup agama lain. Seakan-akan hanya agamanya sendirilah yang benar dan mempunyai hak hidup,sedangkan agama yang lain salah, tersesat, dan terancam hal hidupnya, sedangkan agama yang lain salah, tersesat, dan terancam hak hidupnya, baik di kalangan mayoritas maunpun minorotas. Semangat pendidikan Agama Islam yang sempit itu sudah barang tentu berlawanan secarafundamental dengan semangat pendidikan multikultur dan akan memperlemah persatuan bangsa.

Karena itu, pendidikan multikultur harus direvitalisasi dan direaktualisasi secara kreatif sehingga tidak kehilangan jiwa dan semangatnya. Sampai pada tataran itu, layak kita meneguhkan kembali paragidma multikultur tersebut.peneguhan itu harus ditekankan kepada persoalan kompetensi kebudayaan, sehingga tidak hanya berkutat pada aspek kognitif tapi juga beranjak pada aspek psikomotorik. Peneguhan tersebut bermaksud menggugah kesadaran bahwa multikulturalisme, sebagaimana diungkapkan oleh Goodenough (dalam Husamah.http://www.icrp-online.org), adalah pengalaman normal manusia, ia ada dan hadir dalam realitas empiris.

Untuk itu pengololaan pendidikan agama Islam yang mutikultur tidak bisa dilakukan secara tekn for granted atau trial and error. Sebaliknya, harus diupayakan secara sistematis, terprogram, terintegrasi, dan berkesimanbungan. Dalam kerangka itulah, fungsi pendidikan mutikultur hadir sebagai sebuah proses, terutama ketika seseorang mengembangkan kompotensi dalam beberapa sistem standar untuk memersepsikan dalam beberapa sistem standar 
memersepsikan, mengevaluasikan, meyakini, dan melakukan tindakan. (Lindra Darnela.http://www.uin-sunankalijaga.com)

\section{KESIMPULAN}

Pendidikan multikultural dilatarbelakangi oleh keberadaan masyarakat dengan individuindividu yang beragam latar belakang bahasa dan kebangsaan (nationality), suku (race or etnicity), agama (religion), gender, dan kelas sosial (social class). Keragaman latar belakang individu dalam masyarakat tersebut berimplikasi pada keragaman latar belakang peserta didik dalam suatu lembaga pendidikan (Bank, 1989: 14).

Dalam konteks Indonesia, peserta didik di berbagai lembaga pendidikan diasumsikan juga terdiri dari peserta didik yang memiliki beragam latar belakang agama, etnik, bahasa, dan budaya. Asumsi ini dibangun berdasarkan pada data bahwa di Indonesia terdapat 250 kelompok suku, 250 lebih bahasa lokal (lingua francka), 13.000 pulau, dan 57 agama resmi (Leo Suryadinata, dkk., 2003: 30, 71, 104, dan 179). Paling tidak keragaman latar belakang siswa di lembaga-lembaga pendidikan di Indonesia terdapat pada paham keagamaan, afiliasi politik, tingkat sosial ekonomi, adat istiadat, jenis kelamin, dan asal daerahnya (perkotaan atau pedesaan).

Tulisan ini merupakan hasil penelitian yang dilakukan di beberapa sekolah Sekolah Menengah Atas Negeri (SMAN) di Kota Pontianak. Dari penelitian yang dilakukan diperoleh hasil penelitian tentang penanaman nilai-nilai multikultural melalui pelajaran Pendidikan Agama Islam oleh guru Pelajaran Agama Islam dikota Pontianak, diperoleh kesimpulan:

\section{Pemahaman Guru Agama Terhadap Nilai-nilai Multikultural}

Sebagian besar guru agama Islam di Sekolah Menengah Atas Negeri (SMAN) di Kota Pontianak belum memahami secara utuh tentang wacana multikultural, baik tentang nilai-nilainya maupun tentang pendidikan multikultural itu sendiri, tetapi secara umum para guru telah mengenal dan pernah mendengar tentang apa nilai-nilai multikultural dan pendidikan multikultural. Pemahaman yang kurang oleh para guru pelajaran agama Islam tersebut juga berpengaruh tehadap pandangan mereka tentang Konsep-konsep multikultural dalam kaitannya dengan pluralisme, nilai-nilai multikultural yang ada di masyarakat, nilai-nilai multikultural dalam undang-undang pendidikan, penerapan nilai-nilai multikultural diterapkan dalam pembelajaran di sekolah, urgensi dan signifikansi penanaman nilai-nilai multikultural dalam kaitannya dengan realitas masyarakat Indonesia, serta nilai-nilai multikultural dalam kaitannya dengan beberapa konflik yang terjadi di Indonesia khususnya di khususnya di Kalimantan Barat.

\section{Pengintegrasian Nilai-nilai Multikultural dalam Mata Pelajaran Agama}

Karena pemahaman yang tidak utuh terhadap nilai-nilai multikultural dan pentingnya pendidikan multikultural, maka pengintegrasiannya dalam mata pelajaran, khususnya mata pelajaran agama Islam juga tidak berjalan dengan baik. Sekalipun demikan, sebagian besar para guru telah mengetahui dan memahami ayat-ayat Al-Qur'an atau hadits-hadits yang terkait dengan nilai-nilai multikultural tersebut. Dengan kata lain sebagian besar guru telah menyampaikan ayatayat Al-Qur'an atau hadits-hadits tentang mengahrgai perbedaan dan demokrasi sesuai kurikulum yang ada. Akan tetapi hanya sebatas menyampaikan pelajaran sesuai dengan silabus tanpa melakukan inpropisasi yang dapat menjadikan murid benar-benar memahami dan menghargai perbedaan seperti yang diajarkan oleh Agama Islam. Kalaupun ada guru yang melakukan itu hanya sebagian kecil saja. 


\section{Strategi Pengintegrasian Nilai-nilai Multikulturak Dalam Mata Pelajaran Agama}

Dalam kaitannya dengan strategi pengintegrasian nilai-nilai multikultural dalam mata pelajaran agama. Sebagian besar guruhanya melakukan rutinitas pembelajaran seperti biasa. Tidak ada inovasi yang berarti, pelajaran hanya seperti biasa disampaikan dengan metode ceramah, hanya sebagian kecil saja yang melakukannya dengan model drama, untuk memberikan pemahaman yang utuh kepada siswa tentang bagaiman memahami, menghargai dan menyikapi perbedaan-perbedaan yang ada. $(*)$

\section{REFERENSI}

Abdul Munir Mulkan, Kesalehan Multikultural, Yogyakarta: Al-Ghiyah, 2005.

Aly, Abdullah, Pendidikan Multikultural dalam Tinjanan Pedagogik. Makalah ipresentasikan pada Seminar Pendidikan Multikultural sebagai Seni Mengelola Keragaman, yang diselenggarakan oleh Pusat Studi Budaya dan Perubahan Sosial (PSB-PS) Universitas Muhammadiyah Surakarta, pada Sabtu, 8 Januari 2005.

Azra, Azyumardi, Demokrasi Multikultural . Harian Republika, 12 Agustus 2004.

Pancasila dan Identitas Nasional Indonesia: Perspektif Multikulturalisme. Dalam

Restorasi Pancasila: Mendamaikan Politik. Identitas dan Modernitas. (Bogor: Brighten Press2006).

Blum, Lawrence A. Antirasisme, Multikulturalisme, dan Komunitas Antar-Ras: Tiga Nilai yang Bersifat Mendidik bagi Sebuah Masyarakat Multikultural . Dalam May, Larry, Shari Collins-Chobanian, and Kai Wong (Eds). Etika Terapan I: Sebuab Pendekatan Multikultural. Terjemahan oleh Sinta Carolina dan Dadang Rusbiantoro. Yogyakarta: PT Tiara Wacana.(2001).

Hardi Sujaie, (Makalah) Pemetaan dan Kerawanan Sosial Potensi Konflik di Kalimantan Barat, 2008.

Hefner, Robert W. Politik Multikulturalisme: Menggugat Realitas Kebangsaan. Terjemahan oleh Bernardus Hidayat dari judul asli The Politics of Multiculturalism, Pluralism and Citizenship in Malaysia, Singapore, and Indonesia. Yogyakarta: Kanisius.(2007).

Masdar Hilmy, Menggagas Paradigma Pendidikan Multikulturalisme, Mataram: Ulumuna Volume VII Edisi 12.

M. Ainul Yaqin, Pendidikan Multikultural, Cross Cultural Understanding untuk. Demokrasi dan Keadilan, Yogyakarta: Pilar Media, 2007

M. Amin Abdullah, Pendidikan Agama Era Multikultural Multireligius, Jakarta: PSAP, 2005.

Mun'im A. Sirry, Dolema Islam Dilema Demokrasi, Jakarta: PT. Gugus Press. Jakarta, 2002. 
Ngainun Naim dan Ahmad Syauqi, Konsep dan Aplikasi Pendidikan Multikultural, Yogyakarta: ArRuzz Media 2008.

Saifuddin, Achmad Fedyani. Reposisi Pandangan mengenai Pancasila: Dari Pluralisme ke Multikulturalisme. Dalam Restorasi Pancasila: Mendamaikan Politik Identitas dan Modernitas. Bogor: Brighten Press (2006).

Saudi Patro, Masyarakat Agama dan Pluralisme Keagamaan, Jakarta: Paramadina, 1997.

Siti Martiningsi, PendidikanAlat Perlawanan, Teori Pendidikan Radikal Paulo Preire, Yogyakarta: Resist Book, 2004.

Suparlan, Parsudi. Sukubangsa dan Hubungan Antar Sukubangsa. Jakarta: Yayasan Pengembangan Kajian Ilmu Kepolisian (2005).

Suryadinata, Leo. dkk. Indonesia s Population: Etnicity and Religion in a Changing Political Landscape. Singapore: Institute of Southeast Asian Studies.

Sy. Ibrahim Al-Qadrie, Sosialisasi Pluralisme dan Pendidikan Multikulturalisme Melalui Pendidikan, Makalah 2007.

Syamsul Arifin, Dari Eksklusifisme ke Inklusifisme Menimbang Multikultural dalam Studi Agama, Cisarua Bogor, Universitas Paramadina Jakarta, 2007.

Tilaar, H.A.R. (2004). Multikulturalisme: Tantangan-tantangan Global Masa Depan dalam Transformasi Pendidikan Nasional. Jakarta: Grasindo(2003).

TIM ANFI, Muatan Lokal Pendidikan Multikultural Kalimantan Barat, Untuk Kelas VII SMP-MTs. Pontianak: Institut Dayakologi, 2008.

Undang-Undang Dasar Negara Republik Indonesia Tahun 1945

Undang-Undang Republik Indonesia Nomor 20 Tahun 2003 tentang Sistem Pendidikan Nasional.

Wilfred Cantwell Smith, Memburu Makna Agama, Bandung: Mizan 2004.

Zakiyuddin Baidhawy, Pendidikan Agama Berwawasan Multikulturalisme, Jakarta: Erlangga, 2005.

Abdullah Faqih, Pendidikan Multikultural dan Keadilan Demokrasi, http://www.abdullahfaqih.multply.com/jurnal/item/6/pendidikan

Anita Lie, Pengembangkan Model Pendidikan Multikultural, http://www.kompascetak/0901/54/opini/htm.

Choirul Mahfud, Multikultural dan Demokrasi Lokal, http://www.seputar.indonesia.com.

Ernie Isis Aisyah Amini, Analisis Kebutuhan Pendidikan Multikultural Berbasis Komptensi Pada Siswa SLTP, http://www.ikip-negerisingaraja.go.1d. 
Farid Ari Fandi, Dari Multikultural ke Multikulturalisme, http://www.icrp-online.org.

Hamid Hasan, PendekatanMultikultural Untuk Pendidikan Nasional, www.hasan.htm.

Hero Nugroho, Pendidikan Monokultural Versus Multikultural, http:/ /www.hutankayu.com

Husama, Saatnya Menerapkan Pendidikan Multikultural, http://www.icrp-online.org.

Ki Supriyoko, Pendidikan Masyarakat Multikultural, http:/ /www.kompascetak/0401/26/opini/htm.

Levi Riansyah, Manifestasi Pendidikan Pluralisme dan Multikultural, http://www.averroes.or.id/opini.

Lindra Darnela, Pembelajaran Multikultural: Belajar Pengalaman, http:/ /www.uin.sunankalijagajogyakarta.com

M. Zainuddin, Pluralisme dan Dialog Antar Umat Beragama, http://www.uinmalang.co.id.

Mochtar Buchari, Pendidikan Multikultural, http://www.kompas.cetak/0701/12/opini/htm

Muhaemin el-Ma'hady, Multikultural dan Pendidikan Multikultural, http://www.pendidikan.network.com

Musa Asy'arie, Pendidikan Multikultural dan Konflik Bangsa, http:/ /www.uinsuka.info/sukapressonline.

Nuraini Setyo Mukti, Menggagas Pendidikan Multikultural, http://www.esaipolitiknurani.blogspot.com

Ruslani, Urgensi Pendidikan Multikultural, http://www.suarakarya-online.com/news.

Wilson Langkale, MungkinkabIntegrasi HAM ke Dalam Pelajaran Agama?,http://www.jil.com/opini 